\title{
2-3 超高感度スーパーハープ撮像管カメラ
}

\section{1. まえ がき}

ハイビジョンの発展, 普及には, 良質なソフトの供 給が不可欠である.このためハイビジョンカメラで は, 番組制作の多様化, 高度化に対応可能な高性能機 器の開発が強く求められており，そのひとつが超高感 度で高画質な小型カメラの実現である。

カメラの感度, 画質等は使用する撮像デバイスの特 性に大きく支配される。八イビジョン用の撮像デバイ スにおいても，現在では優れた諸特性を有する CCD が従来の撮像管に取って代わって完全に主流となって いる。しかし, 感度に主眼を置いた場合には, 光電変 換膜に電荷増倍作用を持たせたハープ (HARP：High -gain Avalanche Rushing amorphous Photoconductor）方式と呼ばれる新しい動作方式の撮像管が, 従来型撮像管や CCD に比べてはるかに優位にあるこ とから, 超高感度八イビジョンカメラの実現には, こ の撮像デバイスの適用が必須となる.

本稿では, 最新型のハイビジョン用超高感度・高解 像度撮像管である $2 / 3$ インチ全静電型スーパーハープ 撮像管の概要と, この撮像管のもつ特性を最大限に生 かした新開発の超高感度スーパーハープ撮像管カメラ について紹介する。

\section{2. ハープ方式撮像管}

\section{1 ハープ方式撮像管の動作原理}

図 1 に, ハープ方式撮像管のターゲットの動作原理 を従来型のサチコンの場合と比較して示す. サチコン の場合は入射光で生成された電荷がそのまま出力信号 となる。これに比べハープ方式では, 入射光により生 じた電荷がターゲットに印加された高電界で加速さ れ, 衝突イオン化と呼ばれる作用によって次々と新た な電荷を生成する。このようにハープ方式撮像管に は, ターゲット内で増倍(アバランシェ増倍)された電 荷が出力信号となるので高い感度が得られる。ハープ

\footnotetext{
$\dagger$ 日立電子株式会社 開発研究所

“Super High Sensitivity HARP-tube Camera" by Masaharu Ohoka (Research \& Development Laboratory, Hitachi Denshi Ltd, Tokyo)
}

テレビジョン学会誌 Vol. 50, No. 2, pp. 179 183 (1996)
正会員 大 岡 正 治 ${ }^{\dagger}$

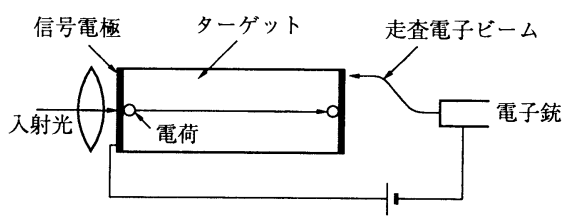

(a) サチコン（動作電界 $1 \times 10^{7} \mathrm{~V} / \mathrm{m}$ )

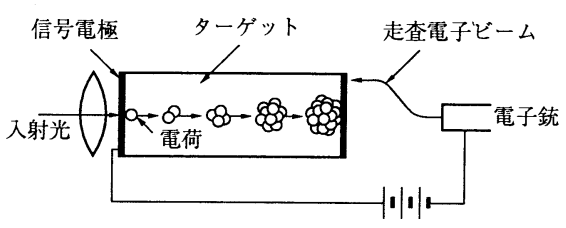

(b) ハープ方式撮像管（動作電界 $1 \times 10^{8} \mathrm{~V} / \mathrm{m}$ )

図 1 ハープ方式撮像管の動作原理

方式撮像管の感度はその動作原理からわかるように， ターゲットの膜厚に依存する。このため膜厚 $2 \mu \mathrm{m}$ のターゲットを用いた初期のハープ方式撮像管 $(2 / 3$ インチ電磁集束・静電偏向型 $)^{1)}$ の感度はサチコンの 約 10 倍であったが, ここで述べる新開発の $2 / 3$ イン チ全静電型スーパーハープ撮像管では，その膜厚を 8 $\mu \mathrm{m}$ として, サチコンの約 80 倍もの高い感度を達成 している.

\section{2 電流-電圧特性}

スーパーハープターゲットに印加される電圧と, 信 号電流, 暗電流の関係を図 2 に示す. 印加電圧を増加 すると信号電流が増加し， $880 \mathrm{~V}$ でサチコンの約 80 倍の感度が得られる.ターゲット電圧の増加に伴っ て, 暗電流も大きくなるが，その值は 80 倍感度の動 作時でも約 $2 \mathrm{nA}$ と小さい. 暗電流が急激に増加する 直前が実用最大感度となる。

\section{3 残像特性}

ハープ方式撮像管の残像は容量性残像である。した がって, 膜厚が厚くターグット蓄積容量が小さくなっ ているスーパーハープ撮像管では, 残像が極めて小さ い.

\section{4 光電変換特性（ガンマ特性）}

$2 / 3$ インチスーパーハープ撮像管の光電変換特性を 


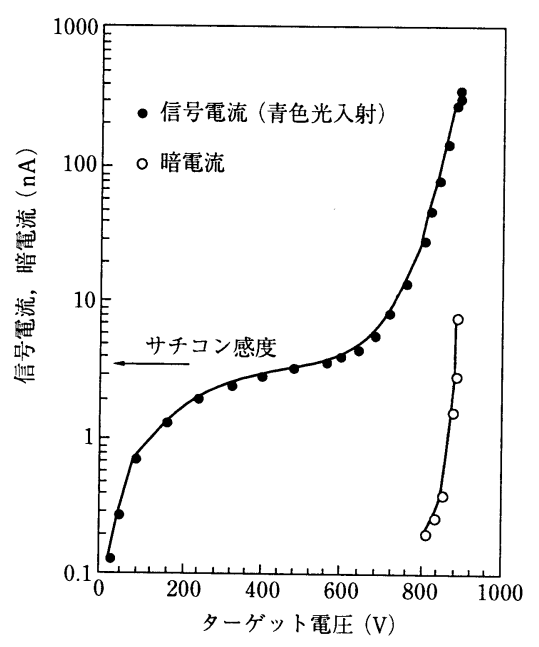

図 2 スーパーハープ管の電流-電圧特性

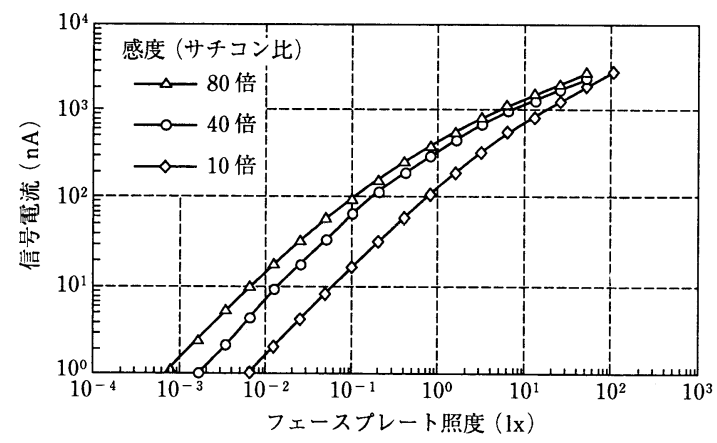

図 3 光電変換特性

図 3 に示す.ターゲット印加電圧が低く, 増倍を生じ ていない動作モードではガンマは約 1 であるが，同図 に示すアバランシェモードでは, 信号電流が大きくな る領域でのガンマが 1 以下となる．これは入射光によ りターゲットのビーム走査側の面電位が上昇すること に起因して，アバランシェモードではハイライトに対 して感度が大きく下がるためである。この作用は信号 の白圧縮を行う効果があることから, 高感度力メラに とっては好ましい特性といえる。

\section{5 解像度特性}

新設計の全静電型電子ビーム系の適用により, 本ス ーパーハープ撮像管では, 高解像度と広ダイナミック レンジの両立を可能にしている2). 図 4 に解像度特性 を示す。画面の中心部のみならず, 周辺領域でも良好 な解像度特性が得られている。

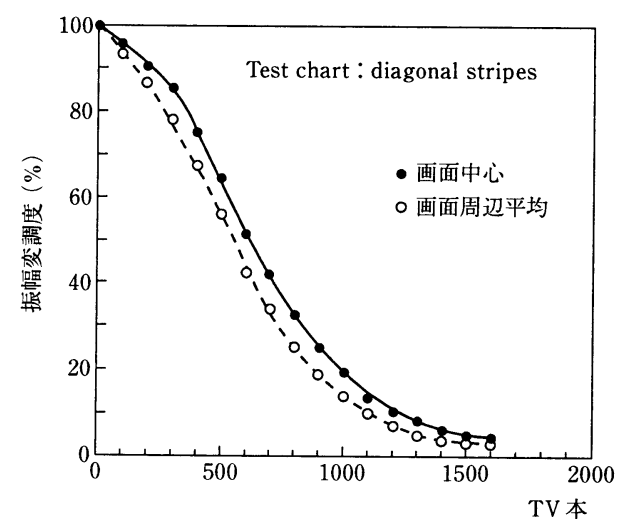

図 4 解像度特性

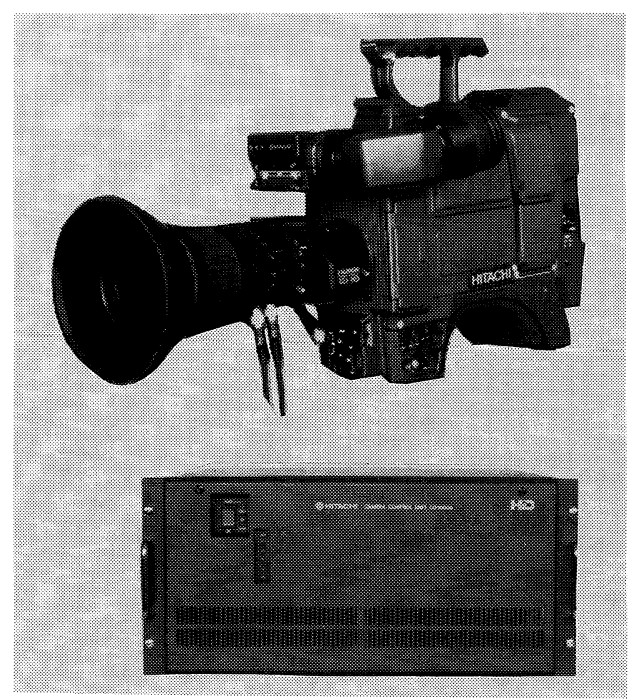

写真 1 カメラの外観（カメラヘッドと CCU）

\section{3. スーパーハープ撮像管カメラ}

スーパーハープ撮像管カメラは, 小型ポータブルカ メラへッド部とカメラ制御器部 (以下 CCU) とで構成 されている(写真 1$)$. カメラヘッドと CCU 間は最大 $300 \mathrm{~m}$ のカメラケーブルで接続される. 以下に, その 特長的なことをしるす。

\section{1 撮像管の駆動回路}

本カメラに使用している全静電型（静電集束, 静電 偏向) 撮像管の有する画面全域にわたる高解像度性や, 低図形歪みの特長を生かすため, 電極電圧の安定化や 偏向用のこぎり波の直線性等には充分な配慮がなされ ている.

\section{スーパーハープ撮像管では, ターゲット電圧が高い}


ことに起因して，画面周辺部でさざ波状の偽信号を生 じることがあるが，この対策として，ターゲットの有 効走査域外をビーム走查してその部分の不要電荷を取 り除くようにした，いわゆる「スキップ走査法」3) が用 いられている。

\section{2 信号処理のディジタル化}

映像信号処理の高機能，高安定化のため, CCUで の信号処理はすべてディジタル化されている．BTA 規格に基づき $74.25 \mathrm{MHz}$ でサンプリング（R， G， B $30 \mathrm{MHz}$ 帯域)を行っている. CCU ではカメラヘッ ドからの信号に対し，ケーブル補償，ディテール補 正，マスキング補正，ブラックストレッチ，白黒クリ ップ等のディジタル処理が行われる。なお，この CCU は外部信号入力端子を持ち, 八イビジョン信号 用ディジタル信号プロセッサとしても使用できる．

\section{3 コンピュータ制御}

撮像管カメラは, CCD カメラと異なりレジストレ ーション調整が必要である。そのかわり CCD カメラ では補正できない，レンズによる倍率色収差等の僅か なレジストレーションずれを補正し，高画質を実現で きる。一方，レジストレーション調整は多項目にわた るため, カメラ内蔵のマイコンにより全項目を自動セ ットアップする. 初期セットアップはカメラ専用のチ ヤートを撮影して行うが，運用時は撮影中の映像から レジストレーション状態を検知してリアルタイムでレ ジストレーション補正を行う，RRC（Real time Reg- istration Compensator）を内蔵している(詳細後述)。 カラーバランス系の調整も, 専用チャートを撮影して マイコンによる自動セットアップが行われる。

\section{4 メモリーファイル}

このカメラでは, 後述のように感度を 3 段階に設定 できる.カメラの調整は各々の感度設定ごとに行う が, ターゲット電圧, カラーバランス, レジストレー ション等に関するCPU データは，いったんメモリー ファイルに格納される．撮影時にはこれらのデータを 呼び出すことにより，所望の感度ではほとんど調整な しにカメラを運用できる。

\section{5 リアルタイムレジストレーション補正(RRC)}

$\mathrm{RRC}$ 機能は, カメラ運用中に起こるレジストレー ションずれ，例えば地磁気の影響，レンズの特性違い によるもの (レンズ交換時等), 回路のドリフト等に起 因するものを自動的に補正する。これにより微細なレ ジストレーションずれが常に補正されるため，極めて 高品位な画像を得ることができる。また，撮像管式力 メラの起動時に必要とされていたレジストレーション 安定化のためのウォーミングアップ時間が不要となる ことから，CCD カメラなみの運用性が期待できる.

リアルタイムレジストレーション補正システムの構 成を図 5 亿示す4).リアルタイムでレジストレーショ ンずれを検出するためには, 撮像中の画像から常時レ ジストレーション状態を観測しなければならない。一 般被写体の R, G，B 3 原色信号間の相互相関性を利

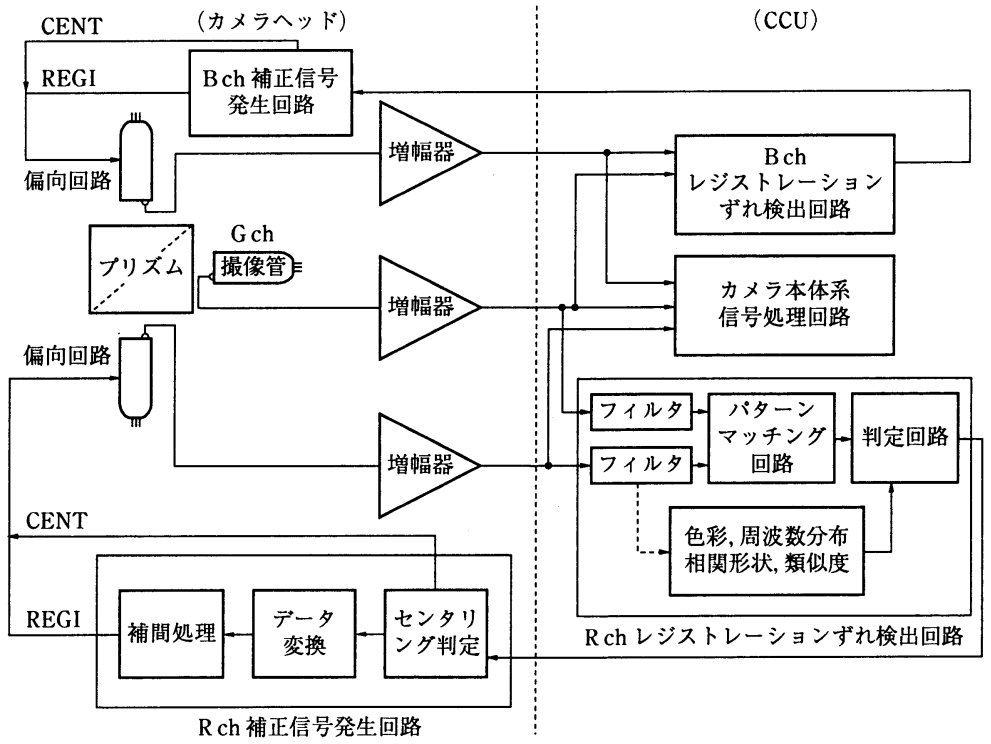

図 5 リアルタイムレジストレーション補正システム 
用し，レジストレーションずれを求める. 画面を水平 方向に 5 点, 垂直方向に 5 点の計 25 点に均等に分割 し, 分割した点を中心として一定領域のデータを抽出 する。それぞれの領域でパターンマッチング法により $\mathrm{R}-\mathrm{G}, \mathrm{B}-\mathrm{G}$ でのレジストレーションずれ量を算出 する ${ }^{5}$.このデータから撮像管の偏向回路を制御して 補正を行う。また，一般被写体では，(1)色彩成分の高 い部分, (2)エッジ信号のない部分, (3)繰り返しパター ンの相関特性がはっきりしない部分については, 誤補 正の可能性があるので補正制御を行わないようにして いる.これらはすべてディジタル処理で行い, 誤差検 出用として 1 チップの専用 LSI が用いられている.

\section{4. カメラの感度と仕様}

スーパーハープ撮像管の感度は, ターゲット電圧に 依存し, 通常のサチコンカメラの 80 倍まで任意の感 度設定が可能である.このため $S / N$ を劣化させるこ となく, 超高感度の撮影ができる ( $N$ はダーク部の) イズ).また，スーパーハープ撮像管はダイナミック レンジが広く大きな信号電流が得られる特性から ${ }^{6}$, 定格信号電流をサチコンの 2 倍に設定して, カメラの $S / N$ を $6 \mathrm{~dB}$ アップした, いわ功高画質撮影モード での運用ができる.すなわちこのモードでは, スーパ 一ハープ撮像管の持つ感度を画質改善に振り向けるこ とになる. カメラの撮影モードと感度の関係を表 1 に 示す．また仕様の主なものを表 2 に示す．

\section{5. カメラの応用}

スーパーハープ撮像管カメラは, 感度が非常に高 く, 解像度, 残像, ダイナミックレンジ等の特性にも 優れている.このため通常の明るさの被写体では高品 質の画像が得られることはもちろん, オーロラのよう に極めて暗く，しかも動きのある被写体であっても， 鮮明に撮影することが可能である. 本カメラ開発の基 礎となった 1 インチ全静電型スーパーハープ管を適用 した試作カメラによるアラスカでのオーロラの撮影例 を写真 2 に示す.

その他, このカメラは

・長焦点レンズとの組合せによるスポーツ中継

・大震災等, 夜間の緊急報道

・照明が禁止されている美術館, 博物館での撮影

・夜行性動物の生態観察

・深い焦点深度が必要とされる立体テレビ撮影への 適用

・深海探查用

等への幅広い応用や, 高速度カメラの展開が考えられ
表 1 カメラの撮影モードと感度の関係

\begin{tabular}{c|c|c|c}
\hline \multirow{2}{*}{ 照度 } & \multicolumn{3}{|c}{ 撮像管感度設定(サチコン比) } \\
\hline \multirow{3}{*}{$2000 \mathrm{~lx}$} & $\times 8$ & $\times 40$ & $\times 80$ \\
\cline { 2 - 4 } & $\mathrm{F} 8$ & $\mathrm{~F} 18$ & $\mathrm{~F} 25$ \\
& \multicolumn{2}{|c|}{\begin{tabular}{c} 
高感度モード $(S / N 45 \mathrm{~dB})$ \\
\cline { 2 - 3 }
\end{tabular}} & $\begin{array}{c}\mathrm{F} 5.6 \\
\text { 高画質モード }(S / N 51 \mathrm{~dB})\end{array}$ \\
\hline
\end{tabular}

表 2 カメラの仕様

\begin{tabular}{|c|c|c|}
\hline & 型 名 & SK-1600 \\
\hline & 撮像管 & 2/3インチスーパーハープ \\
\hline 光 & 光学系 & F 1.4 プリズム \\
\hline \multirow[t]{2}{*}{ 学 } & \multirow[t]{2}{*}{ フィルタ } & ND：4 枚 \\
\hline & & $\mathrm{CC}: 3$ 枚 $+\mathrm{CAP}$ \\
\hline \multirow{4}{*}{ 定 } & \multirow[t]{2}{*}{ 感 度 } & F 1.7 9 lx（最高感度モード） \\
\hline & & F 5.62000 lx（高画質モード） \\
\hline & $S / N$ & 51 dB（高画質モード） \\
\hline & 解像度 & $800 \mathrm{TV}$ 本 $\mathrm{AR} 30 \%$ \\
\hline \multirow[t]{2}{*}{ 格 } & $\begin{array}{l}\text { レジスト } \\
\text { レーション }\end{array}$ & 0.025\%（第一ゾーン） \\
\hline & 消費電力 & 約 $400 \mathrm{VA}(\mathrm{AC} 100 \mathrm{~V})$ \\
\hline \multirow{4}{*}{ 信 } & \multirow[t]{2}{*}{ 入力信号 } & 同期信号 $\quad: 0.6 \mathrm{Vp}-\mathrm{p}$ \\
\hline & & 送り返し信号：1.0 Vp-p（2 入力） \\
\hline & \multirow[t]{2}{*}{ 出力信号 } & $\begin{array}{l}\mathrm{R}, \mathrm{G}, \mathrm{B} \text { (または } \mathrm{Y}, \mathrm{Pr}, \mathrm{Pb} \text { に切替) } \\
\text { 各 } 4 \text { 系統 } \quad: 1.0 \mathrm{Vp}-\mathrm{p}\end{array}$ \\
\hline & & 同期信号４ 4 系統 \\
\hline \multirow{3}{*}{$\begin{array}{l}\text { 寸 } \\
\text { 法 }\end{array}$} & カメラ & $136(\mathrm{~W}) \times 343(\mathrm{H}) \times 353(\mathrm{D}) \mathrm{mm}$ \\
\hline & $\mathrm{CCU}$ & $480(\mathrm{~W}) \times 221(\mathrm{H}) \times 463(\mathrm{D}) \mathrm{mm}$ \\
\hline & $\mathrm{SCU}$ & $450(\mathrm{~W}) \times 133(\mathrm{H}) \times 422(\mathrm{D}) \mathrm{mm}$ \\
\hline
\end{tabular}

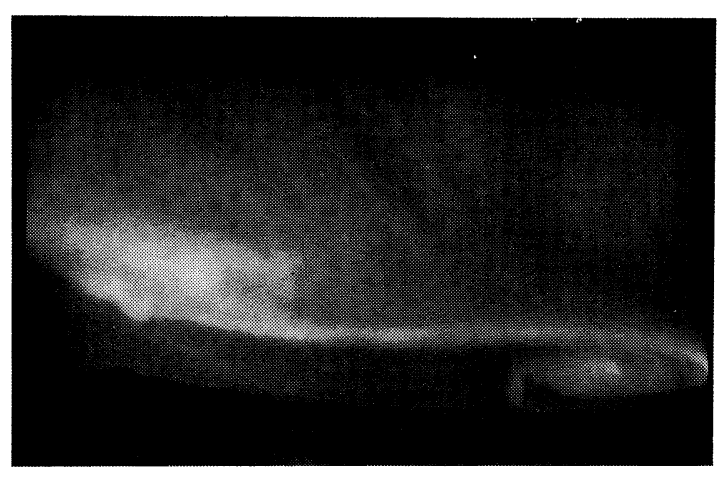

写真 2 撮影例 (ハイビジョン番組「オーロラ〜アラ スカ天空の彩〜」より) 
る。

\section{6. む す び}

CCD カメラが主流となった現在, 撮像管式カメラ の魅力を忘れがちである（高い限界解像度やレンズの 倍率色収差の影響を吸収できる等)。超高感度スーパ 一ハープ撮像管カメラは, CCD カメラでは苦手とす る暗い被写体でも鮮明なハイビジョン映像として捉え てくれる，超高感度撮影の必要性は, 報道番組を含め 今後のハイビジョン番組の多様化の中でますます高ま るものと思われる、スーパーハープ撮像管の特性を充 分引き出した本カメラの多方面での活躍を期待する.

最後に, 本カメラの開発にあたってご指導, ご議論 頂いた NHKの関係各位に感謝の意を表します。

(1995 年 10 月 2 日受付)

〔参考 文 献〕

1）江上ほか：“HARPターゲットを適用したハイビジョン用
高感度撮像管”, テレビ全大, 2-10, pp. 35-36（1987）

2) Masakazu Nanba, et al. : "Super High-Sensitive Camera Tube for HDTV Hand-held Cameras", SPIE, 2416 (Feb. 1995)

3）大岡ほか: “1 インチハーピコンハイビジョンカメラ”, テレ ビ学技報, 15, 62, pp. 19-22（Oct. 1991）

4) 戸村: “ハイビジョンカメラ用実時間レジストレーション補 正システム”,テレビ年次大, 3-9, pp. 57-58（1995）

5) I. Mimura, et al.: "Real-time Registration Compensator for 1" HARPICON Hi-Vision Camera”, SPIE, 1656, pp. 48 -54 (1992)

6）久保田ほか：“HARPターゲットの大信号電流動作特性”, テレビ年次大, 1-3, pp. 5-6 (1991)

7）“目を超えたテレビカメラが捉えたオーロラの映像”，月刊天 文, 59, pp. 22-25 (Dec. 1993)

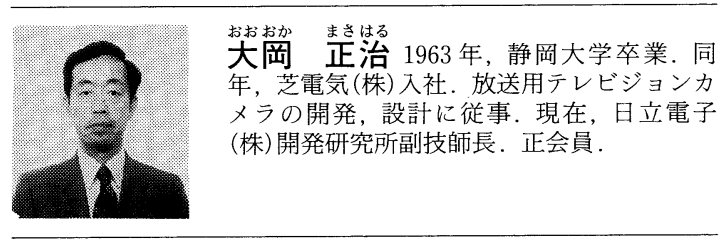

\section{2-4 高 速 カ メ ラ}

\section{正会員 山 下 伸 逸 $^{\dagger}$}

\section{1. まえ がき}

現行方式では従来より各種高速度カメラシステムが 実用化されて㧍り122), スポーツ中継などで活用され ている. 高速度カメラは高い動解像度を持ち, 動きほ けを抑えつつ, なめらかなスローモーション映像を得 ることができる。

一方, ハイビジョンの映像制作機材は, 現行方式で 実現されている機能と同等以上の機能を実現すべく開 発が進められており, 八イビジョンにおいても, 高速 度カメラシステムにより得られる高精細なスローモー ション映像が求められている. 本稿では, 我々の開発 したハイビジョン高速度カメラシステムについて, そ の構成抢よび特性の概要を紹介する。

\section{2. 高速度カメラの方式}

高速度カメラシステムは, 基本的にフレームレート を上げた撮像部と, 高フレームレートの映像信号を記

†キヤノン株式会社 カメラ事業部 DV プロジェクト

"High-speed TV Camera" by Shinichi Yamashita (DV Project, Camera Operations, CANON Inc., Tokyo)

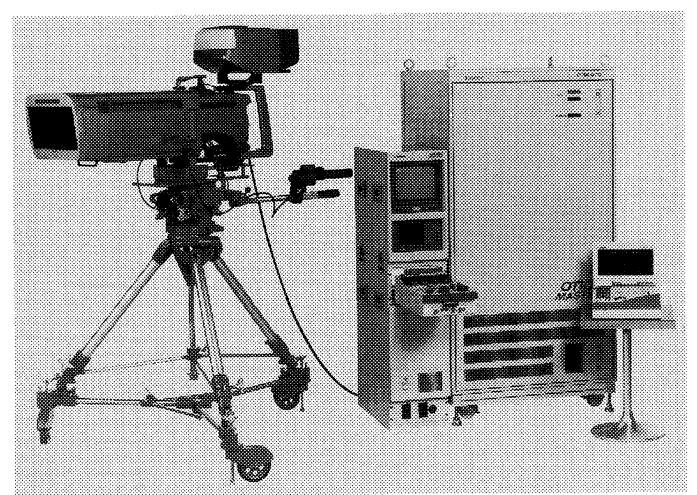

写真 1 高速度カメラシステム

録再生するレコーダ部からなる (写真 1$)$. 高フレーム レートの撮像部を実現する方式としては, 撮像素子の 駆動周波数を上げるか, または撮像素子を多数並列に 用いて等価的にフレームレートを上げることが考えら れる. 本システムでは撮像素子として撮像管を選び, 駆動周波数を上げる方式とした。

高速の撮像部で得られた映像は標準方式とは異なる 